\title{
From Pedagogical Museum to Instructional Material Center: Education Libraries at Teacher Training Institutions, 1890s to 1970s
}

By Ramirose Attebury and Michael Kroth

\begin{abstract}
The development of education libraries cannot be understood outside the context of education history. Changes in educational practices and technology spurred three phases of development in the history of education libraries. Early examples, often called curriculum laboratories, developed as spaces to create educational materials where limited numbers existed. As standardized curriculum grew, common laboratories gave way to curriculum materials centers, which housed materials so that future teachers could preview them. The rise of audio-visual equipment transformed education libraries once again into centers housing a variety of instructional materials. This paper traces the development of education libraries through these three phases.
\end{abstract}

\section{Introduction}

As Sputnik launched into space on October 4, 1957, concerns about how the event would affect libraries were probably not at the forefront of people's minds. But as the realization dawned that the Soviet Union had accomplished something that the United States had not, public scrutiny of the nation's educational system manifested itself into very real changes for educational institutions and the libraries that served them. At the University of Idaho, retired education professor Terry Armstrong recalled the impact the satellite's launch had on the institution's College of Education (personal communication, January 9, 2009). He noted that the event provided the impetus to expand the college's physical presence on campus, eventually resulting in a brand new building devoted solely to the discipline of education. Included in this building was space dedicated for a specialized education library, one that contained current curriculum materials, audiovisual equipment, space-related materials from NASA, and special education materials.

The University of Idaho's College of Education was not alone in its quest to ensure that teachersin-training had access to the latest print and AV equipment that they would likely encounter as they took their first professional positions.

Nationwide, specialized education libraries rushed to ensure they were part of the solution to solving the nation's educational woes. In 1957 a survey of 306 teacher education institutions in the United States revealed that 140 , or $46 \%$, included a library devoted to curriculum and instructional materials (Flandro, 1957). Twelve years later a similar survey of 331 teacher education institutions showed that 304 , or $92 \%$, had these types of libraries and an additional $6 \%$ could identify another entity on campus that provided their services (Ellis, 1969). Clearly the numbers reveal a considerable dedication to the growth and development of education libraries during the 1960s.

Based on these numbers it might be tempting to identify the 1960s as the watershed period for the expansion of education libraries. That the 1960 National Council for the Accreditation of Teacher Education standards mentioned education libraries as a requirement for accreditation lends support to this assumption (Nevil, 1975). Nevertheless, the jump in numbers seen in the 1960s does not reveal the entire story of how these special libraries came to form an integral part of teacher preparation programs. Certainly, education reforms inspired by Cold War fears prompted the development of new libraries and the updating of existing libraries. Still, the fact that nearly half of all teacher education institutions had education libraries prior to the launch of Sputnik indicates that motivations for their creation existed well before global 
hostilities began to threaten American security. This paper seeks to describe not only the expansion of American education libraries during the 1960 s, but also to identify some key points that lead to their development prior to that decade. Beginning with the earliest documented example of an education library in the late 1890s and continuing with their first burst of growth during the 1920s and 1930s, this paper discusses the relationship that these libraries had with educational schools of thought and technological developments throughout the twentieth century.

\section{Studying Education Libraries}

There are varied sources of information available for tracing the development of education libraries, or curriculum materials centers, as they have often been called. Most obvious are those materials in the education and library literature that directly discuss these special libraries. Details can be gleaned from articles that profile individual libraries and dissertations investigating them on a national scale about the reasons behind their creation and about the services and materials they offered. Advice literature, or recommendations from educators about how to create and administer education libraries, also provides a glimpse into the past from the viewpoint of those who felt these libraries were worth the time and energy required to create and sustain them.

Naturally, education libraries did not develop in a vacuum, and librarians alone did not provide the impetus for their widespread creation. Therefore, a discussion of the development of education libraries must be done in the context of larger educational trends and schools of thought. Educators and politicians seeking to make the best school system possible have predictably focused at times on curriculum, textbooks, and technology. Institutions of higher education attempting to train future teachers have done the same, and this led many to focus their efforts on ensuring that preservice teachers had access to the materials they would see in their professional roles. Therefore, it is necessary to consider the literature discussing these aspects of education when studying education libraries as well.
Not all teacher training institutions developed education libraries in the same way or at the same time. Best intentions were sometimes stymied by lack of funds or administrative support. Hence, there is a varied and staggered pattern of development on a national scale, and the literature related to these types of libraries reflects this. Changes in the names of education libraries from curriculum laboratories to curriculum libraries to instructional materials centers reflect different stages of development (and make identifying relevant materials something of a challenge). Understanding that these terms correspond to the various stages of development is helpful when studying education libraries.

An initial spurt of education libraries in the 1920s and 1930s reflected the fact that curriculum practices around the nation were still very much under development. Education libraries, at that time most often called curriculum laboratories, were frequently places for the creation and testing of curriculum materials. Later, as curriculum was determined more by educational administrators at state levels, education libraries grew to be seen less as centers of creation and more as places for pre-service teachers to familiarize themselves with existing materials. The term laboratory thus declined over time in much of the literature discussing these types of libraries. Finally, as the use of audio-visual materials in education grew, education libraries entered a third phase of development, and became, most often, instructional materials centers.

Several approaches were used to identify materials that would help trace the formation of education libraries. Databases consulted include H.W. Wilson's Library Literature Full-Text and Education Index Retrospective, the U.S. Department of Education's ERIC, and EBSCO's Professional Development Collection and Library, Information Science and Technology Abstracts.

General books on the history of teacher preparation and the American school system were located using World Cat Local. In addition, primary source materials surrounding the development of the University of Idaho's College of Education and its education library, the 
Instructional Media Technology Center, were also located in the University of Idaho Archives and Special Collections. Finally, interviews were conducted with a University of Idaho College of Education faculty member present at the time of the IMTC's creation and with the immediate past and current directors of the IMTC.

\section{Pre-1920s}

Long before educational institutions had the desire and means to systematically prepare teachers for the classroom, educators like Horace Mann planted the seeds of hope for a national education system that trained children to take their place as functioning citizens in society. Mann's system of common schools with uniform practices and curriculum did not happen quickly. Graded schools in which children progressed through the same material with others their age were only possible in large cities until the end of the nineteenth century. Even as state, regional, and national education organizations sought to standardize public education practices in the 1890s, many students still attended schools where local control led to a variety of curriculums taught by teachers with little formal training (Reese, 2005). With the curriculum development still very much in its infancy, few teacher education institutions had developed comprehensive education libraries devoted solely to curriculum materials.

Although standard state-adopted curriculum materials were still largely a thing of the future, at least one teacher education institution saw the need early on for collecting the materials that did exist in order to allow education students the opportunity to familiarize themselves with the materials prior to obtaining teaching positions. Colorado State Normal School, an institution devoted to preparing teachers for work in the classroom and later known as the University of Northern Colorado, had an education library as early as 1898 . Roberts (1990) notes that Colorado State Normal School established a "pedagogical museum" from an institutional collection of 7,000 materials so that for pre-service teachers could prepare themselves for the classroom. Materials housed in the "museum" included current textbooks, historical textbooks, and books on the theory of teaching. The fact that the Colorado State Normal School collected widely from existing materials probably reflects the ongoing discussions among education professionals about what courses of study should be taught and what textbooks should be used. The education library at Colorado State Normal School was an idea ahead of its time, yet the library at the normal school received scant notice from later scholars interested in the development of education libraries, probably due to the fact that support for the center waned between 1908 and 1950 (Squire, 1992). Only in the 1950s were curriculum materials again separated from the general library collection to create a special Education Resource Center (Roberts, 1990).

It should be noted that many teachers in the early part of the twentieth century were prepared at normal schools, institutions that offered courses beyond the high school level but that were not as comprehensive as colleges and universities offering bachelor's degrees. Often these schools, like the one in Colorado, had their own libraries. In spite of not being as comprehensive as fouryear institutions, normal schools did offer coursework in a variety of disciplines and their libraries held more than just curriculum materials. It does appear, however, that in some instances these libraries may have been forerunners of later education libraries at larger institutions. Brydges (2009) describes the transformation of the education library at the University of Calgary, which began as a normal school, from a comprehensive normal school library into two separate libraries, a general library serving the entire institution and a smaller curriculum materials center serving the teacher preparation programs. It seems likely that similar transformations could have occurred at other institutions that began as normal schools although further research is needed to verify this assumption.

The development of education libraries would not have occurred without the development of the materials that they came to house. As the years passed early in the twentieth century, debates 
about the nature of education and the use of textbooks among educators began to pave the way for the adoption of textbooks and standardized curriculum. The appearance of progressive education led to cries against rote memorization, textbooks, and physical punishment in the nation's schools. However, even among those educators who espoused this "gentler pedagogy," memorization of facts learned in textbooks offered a tangible way to ensure that students learned the same material (Spencer, 2000).Moreover, in spite of theoretical support for progressive education ideas, the ideas had limited effect on actual classroom experiences. Furthermore, Reese (2005) notes that in the years leading up to the twentieth century, textbook makers promoted their products well enough that a large number of schools nationwide used recitation from the books as a standard form of instruction. Gradually, the seeds of curriculum standardization were sown that would later influence the development of education libraries.

\section{0s and 1930s}

During the early years of the twentieth century debate about how the growing public education system should operate continued to spur changes in the education field. The 1920s and 1930s did see standardization of educational practices grow, albeit slowly, and debates about best practices, including what to do about textbooks, continued. The 1930s saw the growth of public schooling for several reasons: high schools offered a refuge for many teens unable to find work; parents and youths hoped that increased education would lead to better jobs; states began passing both compulsory education laws and child labor laws (Tyack, 1984). Buckingham (1937) suggested that the increase in the number of students led to a shortage of adequately prepared teachers. He saw textbooks as a means of supplementing teacher knowledge in the classroom. However, Bode asked whether textbooks should serve as guides for teachers to use or if they contained absolute truths from which teachers should not deviate. The former idea seemed to offer flexibility and encouragement for educators wanting to create and manipulate their own materials. The latter, on the other hand, would have prompted teacher education institutions to provide their students with opportunities to learn only about those materials that had been vetted and approved by educational leaders.

Inconsistencies in textbook adoption during the 1920s and 1930s inspired widespread debate among educational researchers and practitioners. An entire issue of the 1934 Review of Educational Research was devoted to reviewing studies related to curriculum in institutions of higher education nationwide, including those that prepared teachers for the classroom. Peik (1934) found that the majority of studies indicated there was much variation throughout the curriculum. Whipple (1930), secretary for the National Society for the Study of Education, adamantly opposed standardization and claimed that state prescription, authorship, and printing of textbooks was "certainly one of the most effective schemes ever contrived to discourage initiative, to retard the spread of new ideas, to encourage mediocrity, to hamper the work of the teacher, to increase the cost of the textbook, and to tempt political interference" (p. 51). The earliest education libraries, which encouraged creative creation of curriculum materials, seemed to reflect Whipple's attitudes. However, that the issue was still being asked in the closing years of the 1930s by a leading education book, which had republished Bode's article, suggests no clear answer was in place at the time (Bode, 1937).

A general consensus may be found in the literature that education libraries really began in earnest in the 1920s and 1930s, and Ellis (1969) states that the need for curriculum material production spurred the development of special laboratories for that purpose. In his published dissertation about materials centers, James (1963) concurs and offers the commonly-cited list of the four earliest known centers: those at Western Michigan University, Columbia University, Western Reserve University, and George Peabody College, all institutions with strong education programs at the time. Writing in 1932, Harap adds evidence supporting the idea that education libraries originally developed as places of production. He states that a curriculum laboratory "is essentially a 
work-place in which raw materials are wrought into finished curricular products and in which data are collected, studied, and interpreted" (p.634).

Accounts of individual education libraries that opened during the 1920s and 1930s attest to the importance of curriculum creation and manipulation as a primary function of the center. One of the most famous and influential centers began in order to meet the needs of Florida and Virginia educators in the production of state curriculum materials. In 1932 the Division of Surveys and Field Studies at George Peabody College established a laboratory that provided dedicated space, consultative services, organized materials, editorial services, opportunity for the exchange of ideas, and opportunities to evaluate work already done. By 1936 eight neighboring states had made use of the center to advance their own curriculums (Brewton, 1941). Evincing the increasing awareness of education libraries and their purposes, calls for more began to grow. Writing in 1938, Wood recommended that education libraries have space for students taking regular courses so they might be able to "construct, organize, and improve materials" (p. $345)$.

During these formative years of education libraries, the term "laboratory" was chosen by many institutions, likely reflecting the fact that these spaces functioned as places where curriculum could be designed and tested. It is unsurprising that during the 1920 s those education libraries just mentioned all used the term "laboratory" in their name. Western Michigan University used the term "Textbook and Curriculum Service Laboratory" while Columbia University had a "Curriculum Construction Laboratory" and George Peabody College had a "Laboratory of Education" (McGiverin, 1988). By 1932 Western Michigan University simply referred to their library as the "Curriculum Laboratory" (Harap, 1932). In 1938 Wood offered advice on the organization and administration of a "curriculum laboratory," which he defined primarily as a workroom for students and teachers. The same year, Leary (1938) conducted a study of "curriculum laboratories" nationwide. A 1940 blurb in Curriculum Journal announced the new space devoted to curriculum materials at the University of North Carolina would be called a “curriculum laboratory" (Gwinn, 1940).

That curriculum materials centers were originally called laboratories is perhaps as unsurprising as the fact that one of the first was located at Columbia University. The institution, with a wellknown teacher's college, was also the professional home of John Dewey, who advocated studentcentered, active, problem-based learning. Curriculum laboratories, which allowed teachers to experiment with and create their own curriculum materials exemplified this philosophy. Progressive educators across the country, who rejected rote memorization of facts from textbooks, emulated the practices of the early curriculum laboratories in order to provide handson, cooperative learning centers for future teachers.

\section{Late 1930s and 1940s}

By the 1930s child labor legislation had contributed even further to the growth of the nation's schools, and more and more young people could be found in classrooms rather than at work. This influx of students led to questions about the purpose of the nation's schools. Debates about college versus vocational preparation grew during the 1930s. As Thayer (1965) points out, in the midst of these debates there were, however, still subjects and issues common to all students. Therefore, standard subjects, or "core curriculums," began to develop in schools. Krause (1976) mentions that the 1933 to 1940

Cooperative Study provided the first attempt to identify standards on a national basis. While he notes the study did not lead to the development of a national curriculum, it did lead many states to examine their policies according to the evaluative criteria proposed. Thus, another step toward uniform regulation of educational practices was made, and another reason for establishing facilities to house approved materials was developed.

Coinciding with the push for standard curriculum at the end of the 1930s, curriculum material creation as the primary function of these education 
libraries started giving way to the practice of viewing approved materials. Describing the results of a 1938 Bureau of Education report that surveyed curriculum materials centers nationwide, Leary (1938) reported that viewing materials was the highest ranked activity. Lowest on the list was the editing of materials. Practices at individual libraries during this period reflected the transition between creating and viewing. The University of Idaho claimed to be "in the process of developing a workroom containing a special collection of materials for work on curricular problems and other instructional problems" by 1946 (Idaho Education Survey Commission, 1946, p. 455). In 1949 Brooks wrote about the role of the University of Chicago Center for Instructional Materials as a place of evaluating materials in order to separate the good from the bad, to enable students and teachers to examine materials, and to collaborate with the department of education to teach the effective use of materials in the classroom. Across the country, at UCLA, also during the late $1940 \mathrm{~s}$, the librarian at the education library seemed to lean toward the viewing of established materials as she made it a point to personally contact textbook publishers asking them to provide her center with sample textbooks.

Also by the late 1930s and throughout the 1940s educational leaders began to seek and accomplish the incorporation of non-print materials into the educational system, which eventually led to their incorporation into education libraries. In the mid1940s, the American Council on Education published a statement containing teacher competencies in the area of audio-visual education (Fulton, 1960). Around the same time Grady (1948) wrote "man does not learn by books alone in this day of multi-media communication...This is no less true for the teacher-in-training who, tomorrow, will be the teacher-in-practice. No effort should be spared nor should the necessary support be provided with reluctance for a task so important as that of insuring the optimum learning in a teacher-training program" (p. 311-12).

Not only were theoretical calls for the integration of audio-visual materials heard, but actual practice began to involve these materials as well. The 1947
County Superintendents of Idaho Conference, sponsored by the State Superintendent of Public Instruction, offered a session with demonstrations of AV equipment, including sound motion pictures and opaque projection. Students from North Idaho College's AV education class presented alongside the school's Director of AV Education. On a national scale, the late 1940s also saw Francis Drag undertake a study of education libraries in order to survey services, materials, and administration practices. In spite of some diversity among practices, Drag (1947) suggested that curriculum at that time was becoming more varied, as visual and auditory aids, models, tools, and other paraphernalia replaced reliance solely on books.

\section{0s and 1960s}

National stress about tense worldwide political situations coincided with cries of alarm that the United States' educational system was not keeping pace with technological and global changes. Concerns about the inability of teachers to do their jobs were frequently voiced. Reminiscent of 1930 s suggestions better curriculum materials would safeguard students against inadequately prepared teachers, Johnson points out that calls for "teacher-proofing" the curriculum escalated in the 1950s amidst fears of Russian advances in science and technology (Johnson, 1989). Spring (1976) notes that Cold War strategy included the development of new national curriculums for math, science, and foreign languages. The launch of Sputnik spurred the 1958 passage of the National Defense Education Act, which was used to allocate additional funds for science, math, language instruction, guidance counseling, and audio-visual teaching aids (Idaho State Board of Education, 1958). James (1963) identified Sputnik as one cause of the hysteria that "catapulted the curriculum laboratory into an unprecedented position of significance in the education of pre and in-service teachers" (p. 220).

Calls for a complete redesign of math and science curriculum were loud. In 1960 the National Education Association circulated a draft policy statement proclaiming the pursuit of scientific knowledge as the great goal of education. Rudolph 
(2002) noted that because Americans could not lash out at the real enemy during the Cold War period, they instead turned their attention to the public school system. This led to the National Science Foundation forming a Physical Sciences Study Committee, which devoted itself to updating high school physics textbooks while a similar committee, known as the Biological Sciences Study Committee, led by professors from the University of Colorado at Boulder also attempted to revamp high school curriculum (Rudolph, 2002). An Idaho education bulletin informed teachers in September 1960 that they needed to participate in special training prior to teaching from the PSSC textbook as well as obtain permission from State Department of Education. Physics teachers were encouraged to seek out the training in order to teach the new curriculum as quickly as possible (Engelking, 1960).

Audio-visuals continued to grow in importance in the education field as well. In a dissertation about instructional materials centers in teacher education, Gibbony (1957) noted a lack of interest by current teachers in AV materials during the $1950 \mathrm{~s}$, but she also claimed that evidence of progress could be found in teacher preparation programs nationwide. Idaho State Elementary Supervisor Frances V. Farrell (1958) noted that a good teacher "makes effective use of audio-visual materials in science teaching" (p. 2). On a broader scale a 1952 conference on AV instruction in teacher education was held in Washington, D.C. A diverse array of national associations with an emphasis on education and audio-visual production were invited to attend. The conference concluded with an agreement that there should be established a Council on Audio-Visual Instruction in Teacher Education with a representative from the organization integrated into the U.S. Office of Education. In addition, it was agreed that respective teacher preparation institutions should make permanent adjustments to prioritize AV materials among their students (Reid, 1952).

In spite of calls for inclusion of an audio-visual component in teacher education programs, without a catalyst like Sputnik and formal requirements from accrediting agencies, progress was uneven in this area. A National Education Association (1957) survey indicated that by 1957 nearly half of the nation's teachers still did not feel comfortable with AV materials. In addition, a survey done in 1960 led Stull and Holley (1960) to conclude that education libraries did little other than provide access to print curricular materials. They wrote, "From this survey it is apparent that not only can prospective teachers leave their colleges without coming into contact with all media of communication, but frequently they do" (p. 572). Raurk, Jr. (1963) also admonished teacher preparation institutions for not doing enough to help teachers understand the basics of AV equipment. Still, the fact that criticism was being leveled at teacher preparation institutions meant that the issue was very much alive in the field.

The type of materials that did make their way into the most well-equipped education libraries during the 1950s and 1960s went beyond a chalkboard, maps, and a few filmstrips (Moldstad \& Frey, 1969). In addition to the standard textbooks, tests, workbooks, and children's literature, the advice offered by leading educators for well-equipped education libraries included many suggestions for quality materials. Among the items recommended were games, picture files, charts, pamphlets, resource units, models, transparencies, bulletin boards, opaque projectors, phonographic recordings, record players, felt boards, magnetic boards, overhead projectors, combination filmstrip-slid projectors, tape recorders, cameras, and magnetic-sound motion pictures (Joseph, 1968; Mace, 1993; Wright \& Berry, 1963; Bomar, Heidbreder, \& Neymeyer, 1973).

Faculty members at teacher preparation institutions nationwide would have been well aware of criticism about the lack of comfort new teachers had with many of these types of audiovisual materials. Even more importantly, national accrediting bodies took note of calls for better preparation among pre-service teachers for curriculum materials of all types. Idaho Education News, a newsletter for state educators, noted that the national Department of Audiovisual Instruction, a division of the NEA, planned the "world's greatest audio visual week" at its annual 
convention for "instructors who are troubled by conflicting information and changing audio-visual technology" (Idaho Education News, 1968, p. 14) The combination of calls for new materials and more training plus the ubiquity of audio-visual materials helped to spur formal requirements that up-to-date education libraries be included as a part of teacher preparation. The 1960 and 1967

Standards and Evaluation Criteria for Accreditation of Teacher Education solidified the importance of establishing curriculum centers either as part of main university libraries or as separate units (National Council for the Accreditation of Teacher Education, 1960; The American Association for Colleges of Teacher Education, 1967).

These requirements not only led to the development of new centers that contained both print and audio-visual materials, but they also spurred radical improvements of existing centers as well. While the University of Idaho's College of Education had devoted a small unstaffed room to storing print curriculum materials in the university's Administration Building sometime prior to the 1960s, the space proved inadequate in the face of changing instructional materials. A 1964 report written for the National Council of the Accreditation of Teacher Education at the University of Idaho noted that the lack of space in the Administration Building meant that the faculty were "handicapped in displaying a variety of instructional materials and in using some of the audio-visual materials because these materials and machines cannot be permanently displayed or left in the rooms" (University of Idaho, College of Education, 1963, p. 121). In addition, Nancy Taylor Shrope (personal communication, July 5, 2011), a student at the College of Education at the time, also remembered individual faculty members often had their own collections, but there was no place for students to experience it all together. The NCATE (1960) report noted that a new building for the college was high on the list of priorities to be requested during the 1965 legislative session, a request that would serve to rectify these deficiencies.
An up-to-date education library came to fruition at the University of Idaho in 1969. Indicative of the significance education libraries had come to have in teacher preparation programs, the new College of Education building, which opened in January, contained dedicated space for a library devoted solely to instructional materials. Everett V. Samuelson, the Dean of the College of Education, tasked Nancy Shrope, then a library science education student, with creating the library's layout. Reflecting the importance of all types of instructional materials the library was named the Instructional Materials Center upon its opening. The original undated policies and procedures manual for the center states its purpose was "to provide a central location for a wide range of current educational print and non-print materials, equipment, production facilities, and services for its faculty and students" (University of Idaho, College of Education, n.d., p. 1).

\section{0s}

By the early 1970s the Instructional Materials Technology Center at the University of Idaho was firmly established on campus. With two qualified faculty members on staff, the center was able to collect, maintain, control, and disseminate "a variety of instructional materials and media" (University of Idaho, College of Education, 1973, p. 18). The Center was formally given a budget in 1971, and it offered equipment such as cassette recorders and synchronizers, video cameras, projectors, record players, and transparencies. Services offered included the production of instructional aides, video production, and the maintenance and circulation of instructional materials. In addition, state-approved curriculum materials, including textbooks and supplements, and eventually children's books and encyclopedia sets made their way into the center. Shrope (personal communication, July 5, 2011) also noted that the backside of the room had booths with prerecorded lessons and headphones to listen to them. She further noted classes at the college incorporated the center's mimeographs, overheads, and other audio-visual equipment. By 1977 the center had one full-time staff member, dedicated solely to the IMTC, whose salary was split between appropriated funds and federal 
funds, and two work study students who each worked ten-hours per week (University of Idaho, College of Education, 1977).

The University of Idaho was not alone in formalizing support for an education library on its campus. Wheeler notes at the beginning of the decade that education journals were filled with descriptions of instructional materials centers, their organizational structures, and the equipment they housed. He also noted that federal aid was helping to fund many of the centers while conferences devoted to the discussion of their management were additional signs of their popularity (Wheeler, 1973). The types of materials recommended for inclusion in education libraries, or media centers as they were often called, increased throughout the 1970s. In addition to other standard equipment, Bomar, Heidbreder, \& Neymeyer (1973) recommended headsets, copy machines, microfilm and fiche readers, and repair equipment. A 1977 update to the NCATE Standards for Accreditation of Teacher Education described an ideal educational library as one that offered sufficient holdings and adequate staffing to meet the needs of both students and faculty members (Houlihan, 1978).

\section{Conclusion}

A long road stretched between the nation's first pedagogical "museum" and the accreditationrequired, institutionally-supported education libraries of the later twentieth century. Sputnik glared alarmingly as a speed bump along the way, but it provided momentum for the development of teacher-preparation libraries. It was not, however, the only object along the way. New ideas, innovative instructional strategies, and technological advancements also sped the course of progress. Each changed the educational landscape of the United States, and in doing so fueled changes to libraries serving teacherpreparation institutions. Although education libraries certainly did not stop developing and changing after the 1970s, for the most part their presence was firmly established on campuses nationwide. From centers of curriculum development, to libraries housing approved print materials, to adopters of audio-visual equipment, education libraries had morphed into vital components of preparing teachers for the classroom.

Today education libraries are common fixtures in education programs, perhaps even taken for granted as resources in the preparation of future teachers. As economic challenges continue to plague many sectors of the educational landscape, it is important to understand how and why education libraries came to exist on so many college and university campuses. Additional research could help to convince administrators and politicians that these libraries have long played a valuable role in the country's education system, and that they continue to do so today. This paper is a first step in better understanding the changes that education libraries underwent from their inception to today. An understanding of the continual adaptations these libraries have undertaken in more recent years in order to meet changing needs of teacher preparation may help to solidify their importance in the minds of everyone interested in the nation's educational system.

\section{Reference List}

American Association of Colleges for Teacher Education. (1967). Standards and evaluative criteria for the accreditation of teacher education: A draft of the proposed new standards, with study guide. Washington, D.C.: AACTE.

Bode, B. (1937). On the use of textbooks. In H.L. Caswell \& D.S. Campbell (Eds.), Readings in curriculum eevelopment (108-110). New York: American Book Company.

Bomar, C.P., Heidbreder, M.A., \& Neymeyer, C.A. (1973). Guide to the development of educational media selection centers. Chicago: American Library Association.

Brewton, J.E. (1941). The Peabody curriculum laboratory. The Bulletin of the National Association of Secondary School Principals, 25, 16-21.

Brooks, A.R. (1949). The role of instructional materials centers in schools and colleges. The School Review, 57(8), 425-432.

Browne, R. E. (1961). Bulletin of the California State Department of Education. 
Sacramento, CA: California State

Department of Education.

Brydges, B. (2009). A century of library support for teacher education in Calgary. Education Libraries, 32(1), 4-11.

Buckington, B.R. (1937). The relation of the curriculum to the textbook. In H.L Caswell \& D.S. Campbell (Eds.), Readings in curriculum Development (110-113). New York: American Book Company.

Drag, F. (1947). Curriculum laboratories in the United States: A research study. San Diego, CA: Office of the Superintendent of Schools.

Ellis, E.V. (1969). The role of the curriculum laboratory in the preparation of quality teachers. Tallahassee, FL: Florida A\&M University Foundation.

Engelking, D.F. (1960). Fall Bulletin. Boise, ID: State of Idaho Department of Education.

Farrell, F. V. (1958). Philosophy, evaluation and improvement of Idaho elementary schools. Boise, ID: Idaho State Superintendent of Public Instruction.

Fulton, W.R. (1960). Audio-Visual competence and teacher preparation. Journal of Teacher Education, 11, 492-496.

Gibbony, H.L (1957). The instructional materials center in teacher education. (Unpublished doctoral dissertation.) Ohio State University, Columbia, $\mathrm{OH}$.

Grady, M.B. (1948). Nonbook materials in a teacher college library. College and Research Libraries, 9(4), 311-315, 322.

Gwynn, J.M. (1940). North Carolina builds curriculum laboratory," Curriculum Journal 11(2),77-79.

Harap, H. (1932). The curriculum laboratory. New York State Education , 19, 634.

Houlihan, B. (1978). The university curriculum library: Evaluate, update, renovate. Curriculum Journal, 17(5), 361-363.

Idaho County Superintendents' Conference Program. (1947). Boise: State Superintendent of Public Instruction. Idaho Education Survey Commission (1946). Public education in Idaho: A report of the Idaho Education Survey Commission. Nashville, TN: Division of Surveys and
Field Services, George Peabody College for Teachers.

Idaho State Board of Education (1958). 23 ${ }^{\text {rd }}$ Biennial Report of the Idaho State Board of Education.

James, M.L. (1963). The curriculum laboratory in teacher education institutions: Its essential characteristics. (Unpublished doctoral dissertation). University of Connecticut, Storrs, CT.

Johnson, W.R. (1989). Teachers and teacher training in the $20^{\text {th }}$ Century," in D. Warren (Ed.) American Teachers: Histories of a profession at work (237-256). New York: Macmillan.

Joseph, S.F. (1968). Curriculum materials center updates teachers," Catholic School Journal 68, 29-30.

Krause, L.L. (1976). Accreditation standards and curriculum. In O.L. Davis, Jr. (Ed.)

Perspectives on curriculum development, 1776-1976 (173). Washington, D.C.:

Association for Supervision and Curriculum Development.

Leary, B.E. (1939). Survey of curriculum laboratories, Curriculum Journal, 9, 350354.

Mace, J. M. (1993). The importance of curriculum materials centers in the academic library. Library Mosaics 4, 22-23.

McGiverin, R. (1988). Curriculum materials centers: A descriptive study. Behavioral \& Social Sciences Librarian 6(3/4), 119-127.

Moldstad, J. \& Frey, H. (1969). A complete materials center. In N.P. Pearson \& L.A. Butler (Eds.) Instructional Materials Centers: Selected Readings (191-193). Minneapolis, MN: Burgess Pub.

National Council for the Accreditation of Teacher Education (1960). Standards and guide for accreditation of teacher education. Washington, D.C.: NCATE.

National Education Association (1957). The status of the American public-school teacher. NEA Research Bulletin, 35(1), 1-175.

Nevil, L. (1975). A survey of curriculum laboratories in selected colleges in Pennsylvania. Willes-Barre, PA: Wilkes College. 
Peik, W.E. (1934). Curriculum investigations at teacher-training, college, and university levels. Review of Educational Research, 4(2), 191-198.

Raurk, Jr., H.C. (1963). It's IMC for 1963: The third year of the decisive decade.

Educational Screen and Audiovisual Guide, 42(12), 674-680.

Reese, W.J. (2005). America's public schools: From the common school to No Child Left Behind. Baltimore, MD: The Johns Hopkins University Press.

Reid, S. (1952). Audio-Visual instruction in teacher education: Report of a conference in Washington, D.C. on May 13-14, 1952. Washington D.C.: Federal Security Agency Office.

Roberts, F.X. (1990). An early example of a curriculum materials collection in an institution of teacher education. Behavioral \& Social Sciences Librarian, 9(1), 21-28.

Rudolph, J.L. (2002). Scientists in the classroom: The cold war reconstruction of American science education New York: Palgrave Macmillan.

Spencer, D. (2000). Teachers' work: Yesterday, today, and tomorrow. In T.L. Good (Ed.), American education: Yesterday, today, and tomorrow (53-83). Chicago: University of Chicago Press.

Spring, J. (1976). The sorting machine: National educational policy since 1945. New York: David McKay Company, Inc.

Squire, J.S. (1992). Curriculum materials: The educational resources service collection at the James A. Michener Library, UNC. Colorado Libraries, 40-42.

Stull, L. \& Holley, E.G. (1960). Some materials centers in the Midwest. Journal of Teacher Education, 11(4), 570-572.

Thayer, V.T. (1965). Formative ideas in American education: From the colonial period to the present. New York: Dodd, Mead \& Company.

Tyack, D., Lowe, R., Hansot, E. (1984). Public schools in hard times: The great depression and recent years. Cambridge, MA: Harvard University Press.
University of Idaho, College of Education. (n.d.) IMC Policy and Procedure Manual. Moscow, ID: Instructional Materials Technology Center, University of Idaho.

University of Idaho, College of Education. (1963). A report to the national council for the accreditation of teacher education. University of Idaho Library Special Collections and Archives.

University of Idaho, College of Education (1973). A report to the National Council on the Accreditation of Teacher Education. University of Idaho Special Collection and Archives.

University of Idaho, College of Education (1977). A report of teacher education programs at the University of Idaho: Prepared for the Office of Higher Education. Moscow, ID: University of Idaho.

Wheeler, R. ( 1973). IMC concept grows here. In N.P. Pearson \& L.A. Butler (Eds.) Learning resource centers: Selected readings (16-20). Minneapolis, $\mathrm{MN}$ : Burgess Publishing Co.

Whipple, G.M. (1930). The selection of textbooks. American School Board Journal, 80(5), 51-53.

Wood, H.B. (1938). How to organize a curriculum laboratory. Curriculum Journal, 9, 345359.

Wright, C.W. \&. Berry, K.R. (1963). At Central Washington State College: All service under one roof, buildings equipped for AV utilization. Audiovisual Instruction 8, 222223.

\section{Ramirose Attebury}

Assistant Professor

University of Idaho

rattebur@uidaho.edu

\section{Michael Kroth}

Associate Professor

University of Idaho

University of Idaho Library

PO Box 442350

Moscow, ID, 83844 